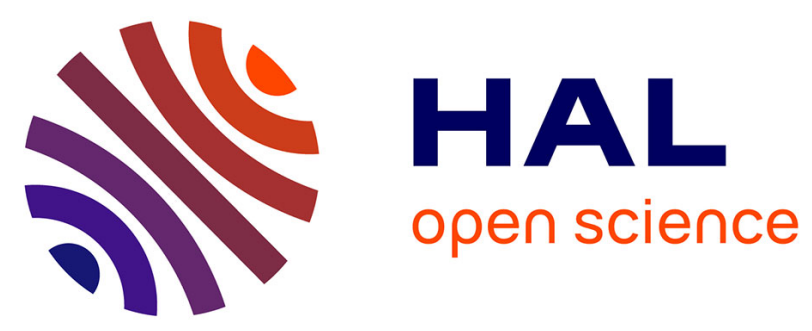

\title{
Kinetics of Cytomegalovirus (CMV) pp65 and IE-1-Specific IFN $\gamma$ CD8+ and CD4+ T Cells During Episodes of Viral DNAemia in Allogeneic Stem Cell Transplant Recipients: Potential Implications for the Management of Active CMV Infection
}

Nuria Tormo, Carlos Solano, Isabel Benet, José Nieto, Rafael de La Cámara, Ana García-Noblejas, María Ángeles Clari, Marifina Chilet, Javier López, Juan Carlos Hernández-Boluda, et al.

\section{To cite this version:}

Nuria Tormo, Carlos Solano, Isabel Benet, José Nieto, Rafael de La Cámara, et al.. Kinetics of Cytomegalovirus (CMV) pp65 and IE-1-Specific IFN $\gamma$ CD8+ and CD4+ T Cells During Episodes of Viral DNAemia in Allogeneic Stem Cell Transplant Recipients: Potential Implications for the Management of Active CMV Infection. Journal of Medical Virology, 2010, 82 (7), pp.1208. 10.1002/jmv.21799 . hal-00552412

\author{
HAL Id: hal-00552412 \\ https://hal.science/hal-00552412
}

Submitted on 6 Jan 2011

HAL is a multi-disciplinary open access archive for the deposit and dissemination of scientific research documents, whether they are published or not. The documents may come from teaching and research institutions in France or abroad, or from public or private research centers.
L'archive ouverte pluridisciplinaire HAL, est destinée au dépôt et à la diffusion de documents scientifiques de niveau recherche, publiés ou non, émanant des établissements d'enseignement et de recherche français ou étrangers, des laboratoires publics ou privés. 


\section{Kinetics of Cytomegalovirus (CMV) pp65 and IE-1-Specific IFNy CD8+ and CD4+ T Cells During Episodes of Viral DNAemia in Allogeneic Stem Cell Transplant Recipients: Potential Implications for the Management of Active CMV \\ Infection}

\begin{tabular}{|c|c|}
\hline Journal: & Journal of Medical Virology \\
\hline Manuscript ID: & JMV-09-1679.R1 \\
\hline Wiley - Manuscript type: & Research Article \\
\hline $\begin{array}{r}\text { Date Submitted by the } \\
\text { Author: }\end{array}$ & $10-F e b-2010$ \\
\hline Complete List of Authors: & $\begin{array}{l}\text { Tormo, Nuria; Hospital Clínico Universitario, Valencia, Spain, } \\
\text { Microbiology Service } \\
\text { Solano, Carlos; Hematology and Medical Oncology Service, Hospital } \\
\text { Clínico Universitario, Valencia, Spain } \\
\text { Benet, Isabel; Hospital Clínico Universitario, Valencia, Spain, } \\
\text { Hematology and Medical Oncology Service } \\
\text { Nieto, José; Hospital Morales Meseguer, Murcia, Spain, Hematology } \\
\text { Service } \\
\text { de la Cámara, Rafael; Hospital de La Princesa, Madrid, Spain, } \\
\text { Hematology Service } \\
\text { García-Noblejas, Ana; Hospital de La Princesa, Madrid, Spain, } \\
\text { Hematology Service } \\
\text { Clari, María; Hospital Clínico Universitario, Valencia , Spain, } \\
\text { Microbiology Service } \\
\text { Chilet, Marifina; Hospital Clínico Universitario, Valencia , Spain, } \\
\text { Microbiology Service } \\
\text { López, Javier; Hospital Ramón y Cajal, Madrid, Spain, Hematology } \\
\text { Service } \\
\text { Hernández-Boluda, Juan; Hospital Clínico Universitario, Valencia, } \\
\text { Hematology and Medical Oncology Service } \\
\text { Remigia, María; Hospital Clínico Universitario, Valencia, Hematology } \\
\text { and Medical Oncology Service } \\
\text { Navarro, David; Hospital Clínico Universitario. School of Medicine, } \\
\text { Microbiology }\end{array}$ \\
\hline Keywords: & Cytomegalovirus, CD8, CD4, immunity, active CMV infection \\
\hline
\end{tabular}




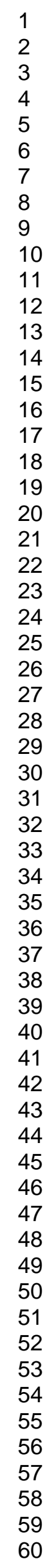

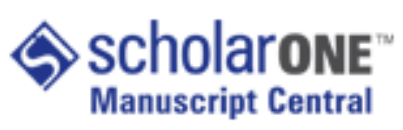

13

14

15

16

18

19

20

22

23

25

26

27

29

30

32

33

34

35

36

39

40

41

43

44

45

46

47

48

50

51

52

53

54

56

57

58

60

John Wiley \& Sons 
2 Kinetics of Cytomegalovirus (CMV) pp65 and IE-1-Specific IFN $\gamma \mathrm{CD8}^{+}$and $\mathrm{CD4}^{+}$

3 T Cells During Episodes of Viral DNAemia in Allogeneic Stem Cell Transplant

4 Recipients: Potential Implications for the Management of Active CMV Infection 5

6 Nuria Tormo, ${ }^{1}$ Carlos Solano, ${ }^{2,3}$ Isabel Benet, ${ }^{2}$ José Nieto, ${ }^{4}$ Rafael de la Cámara, ${ }^{5}$ Ana

7 Garcia-Noblejas, ${ }^{5}$ María Ángeles Clari, ${ }^{1}$ Marifina Chilet, ${ }^{1}$ Javier López, ${ }^{6}$ Juan Carlos 8 Hernández-Boluda, ${ }^{2}$ María José Remigia, ${ }^{2}$ and David Navarro, ${ }^{1,7 *}$

$10{ }^{1}$ Microbiology Service, Hospital Clínico Universitario, Valencia, Spain

$11{ }^{2}$ Hematology and Medical Oncology Service, Hospital Clínico Universitario, Valencia, 12 Spain

$13{ }^{3}$ Department of Medicine, School of Medicine, University of Valencia, Valencia, Spain

$14{ }^{4}$ Hematology Service, Hospital Morales Meseguer, Murcia, Spain

$15 \quad{ }^{5}$ Hematology Service, Hospital de La Princesa, Madrid, Spain

$16{ }^{6}$ Hematology Service, Hospital Ramón y Cajal, Madrid, Spain

$17{ }^{7}$ Department of Microbiology, School of Medicine, University of Valencia, Valencia, 18 Spain.

20 Correspondence: David Navarro, Microbiology Service, Hospital Clínico Universitario, 21 and Department of Microbiology, School of Medicine, Av. Blasco Ibáñez 17, 46010 22 Valencia, Spain. Phone: 34(96)3864657; Fax: 34(96)3864173; E-mail: 23 david.navarro@uv.es.

24 Running head: CMV-specific immunity during episodes of CMV DNAemia 


\section{ABSTRACT}

27 The dynamics of CMV pp65 and IE-1-specific IFN $\gamma$-producing CD8 ${ }^{+}\left(\mathrm{IFN} \gamma \mathrm{CD} 8^{+}\right.$) and $\mathrm{CD}^{+}\left(\mathrm{IFN} \gamma \mathrm{CD}^{+}\right) \mathrm{T}$ cells and CMV DNAemia were assessed in 19 pre-emptivelytreated episodes of active CMV infection. Peripheral counts of IFN $\gamma \mathrm{CD}^{+}$and IFN $\gamma$

$30 \mathrm{CD}^{+} \mathrm{T}$ cells inversely correlated with CMV DNAemia levels $(P=<0.001$ and $P=0.003$, 31 respectively). A threshold value of 1.3 cells/ $\mu \mathrm{L}$ predicting CMV DNAemia clearance was established for IFN $\gamma \mathrm{CD}^{+} \mathrm{T}$ cells (PPV, 100\%; NPV, 93\%) and for IFN $\gamma \mathrm{CD}^{+}{ }^{\mathrm{T}}$ cells (PPV, 100\%; NPV, 75\%). Undetectable T-cell responses were usually observed at the time of initiation of pre-emptive therapy. Either a rapid (within 7 days) or a delayed (median 31 days) expansion of both T-cell populations concomitant with CMV DNAemia clearance was observed in 5 and 8 episodes, respectively. An inconsistent or a lack of expansion of both T-cell subsets was related to a persistent CMV DNAemia.

Robust and maintained CMV-specific T-cell responses after CMV DNAemia clearance and cessation of antiviral therapy were associated with a null incidence of relapsing infections at least during the following month. Data obtained in the present study may

41 be helpful in the design of therapeutic strategies for the management of active CMV 42 infections in the allo-SCT recipient.

44 Key words: Cytomegalovirus, $\mathrm{IFN} \gamma \mathrm{CD} 8^{+}$and $\mathrm{CD}^{+} \mathrm{T}$ cells, active $\mathrm{CMV}$ infection, 45 immunological monitoring, stem cell transplantation. 
INTRODUCTION

52 Pre-emptive antiviral therapy has been adopted by most transplant centers as the first-

53 choice strategy for the prevention of cytomegalovirus (CMV) disease following 54 allogeneic stem cell transplantation (allo-SCT) [Boeckh et al., 2003; Griffiths et al., 55 2008]. While this strategy has been shown to dramatically reduce the incidence of early 56 CMV disease [Boechkh et al., 2003; Ljungman, 2008], it probably results in over57 treatment, as a number of patients who would never progress to CMV disease are treated nevertheless [Ljungman, 2006; Avetisyan et al., 2007]. Hopes have been raised that routine immunological monitoring for CMV-specific T-cell immunity may improve 60 the management of active infection, leading to a more targeted use of antivirals and 61 allowing the identification of patients at high risk for relapsing infections and end-organ

62 disease. Nevertheless, to date, assessment of CMV-specific T-cell immunity has not had 63 a major impact on clinical management of active CMV infection. In order to design 64 potential intervention strategies based on immunological monitoring, characterization of 65 the kinetics of functional CMV-specific $\mathrm{T}$ cells during episodes of active CMV 66 infection is required. Studies addressing this issue are, however, scarce [Aubert et al., 67 2001; Foster et al., 2002; Widmann et al., 2008]. Resolution of episodes of active CMV infection in the allo-SCT setting appears to be ultimately dependent on the expansion of

69 functional CMV-specific T cells in response to CMV replication [Quinnan et al., 1982;

70 Reusser et al., 1991; Riddell et al., 1992]. In this regard, we have previously shown that 71 the lack of prompt expansion of CMV pp65 and IE-1-specific IFN $\gamma$-producing CD8 ${ }^{+}$ 72 (IFN $\left.\gamma \mathrm{CD}^{+}\right)$and $\mathrm{CD}^{+}\left(\mathrm{IFN} \gamma \mathrm{CD} 4^{+}\right) \mathrm{T}$ cells is associated with rising levels of pp65 73 antigenemia and DNAemia during pre-emptive therapy and prolonged duration of 74 antiviral treatment [Tormo et al., 2009]. In the present study, the dynamics of CMV75 specific IFN $\gamma \mathrm{CD}^{+}$and IFN $\gamma \mathrm{CD}^{+} \mathrm{T}$ cells, which we have previously shown to confer 
76 protection against CMV infection [Solano et al., 2008], and those of CMV DNAemia

77 were assessed in a number of episodes of active CMV infection. Data obtained in the

78 present study are of potential interest for the therapeutic management of active CMV

79 infections in the allo-SCT recipient.

80

81

82

83

84

85

86

87

88

89

90

91

92

93

94

95

96

97

98

99

100

John Wiley \& Sons 


\section{Patients}

103 Patients undergoing allo-SCT between December 2008 and May 2009 at the

104 participating hospitals were eligible for inclusion. The study was approved by the Ethics

105 Committees. All patients gave their informed consent to participate in the study. CMV-

106 seronegative patients receiving a graft from a CMV-seronegative donor were not

107 included in the study. Only episodes of active CMV infection treated pre-emptively

108 were included for analysis. The end of the study period was June $22^{\text {th }} 2009$. Clinical and

109 demographic data of the patients are shown in Table I.

\section{Management of active CMV infection}

111 Virological monitoring of CMV infection was performed by use of the pp65

112 antigenemia assay (Diagnostics ${ }^{\circledR}$ CMV pp65 Antigenemia Immunofluorescence assay,

113 Chemicon International, Temecula, CA, USA), and/or a plasma real-time PCR assay

114 (CMV real-time PCR, Abbott Molecular, Des Plaines, IL, USA, or LightCycler CMV

115 Quant Kit, Roche, Branchburg, NJ, USA) as previously reported [Solano et al., 2001;

116 Gimeno et al., 2008]. Pre-emptive therapy with oral valganciclovir (900 mg/12 h) or i.v.

117 ganciclovir $(5 \mathrm{mg} / \mathrm{Kg} / 12 \mathrm{~h})$ was initiated upon a positive antigenemia result $(\geq 1 \mathrm{pp} 65$

118 positive cells/200,000 cells) or detection of $>1000$ CMV DNA copies $/ \mathrm{mL}$ in plasma

119 depending on the participant institution, and discontinued following 2 consecutive

120 negative antigenemia or plasma PCR results (also depending on the participant hospital)

121 obtained 3 to 7 days apart after a minimum of 2 weeks of treatment. Foscarnet (i.v. 60

$122 \mathrm{mg} / \mathrm{Kg} / 12 \mathrm{~h}$ ) was used instead of ganciclovir in patients with severe neutropenia, and in

123 some patients not responding to ganciclovir therapy after 3 weeks of treatment. For

124 analysis purposes, the duration of a given episode was that comprised between the day

125 of initiation of pre-emptive therapy and the day of the first negative DNAemia result. 
126 Diagnosis of CMV disease was achieved as previously reported [Solano et al., 2001;

127 Gimeno et al., 2008]. When clinically indicated, patients received transfusions of 128 leukocyte-depleted and irradiated packed red cells and platelets. Immunological monitoring

130 Enumeration of $\mathrm{CMV}$-specific $\mathrm{IFN} \gamma \mathrm{CD}^{+}$and $\mathrm{IFN} \gamma \mathrm{CD}^{+} \mathrm{T}$ lymphocytes was 131 carried out by flow cytometry for ICS (BD Fastimmune, BD-Beckton Dickinson and 132 Company-Biosciences, San Jose, CA, USA) as described previously [Solano et al., 133 2008]. Briefly, whole blood was simultaneously stimulated with two sets of 15-mer 134 overlapping peptides encompassing the sequence of pp65 and IE-1 CMV proteins (2 $135 \mu \mathrm{g} / \mathrm{ml} /$ peptide), obtained from JPT peptide Technologies GmbH (Berlin, Germany), in 136 the presence of $1 \mu \mathrm{g} / \mathrm{ml}$ of costimulatory mAbs to CD28 and CD49d for $6 \mathrm{~h}$ at $37^{\circ} \mathrm{C}$.

137 Brefeldin A $(10 \mu \mathrm{g} / \mathrm{ml})$ was added for the last $4 \mathrm{~h}$ of incubation Cells were 138 permeabilized and stained with a combination of labeled moAbs (anti-IFN $\gamma$-FITC, anti139 CD69-PE, anti-CD4 or CD8-PerCP-Cy5.5 and anti-CD3-APC when the IFN $\gamma$ CD8 ${ }^{+}$kit 140 was used). Cells were analyzed on a FACSCalibur flow cytometer using CellQuest 141 software (BD Biosciences Immunocytometry Systems). $\mathrm{CD}^{+}$and $\mathrm{CD} 8^{+}$events were 142 gated and then analyzed for the CD69 activation marker and IFN $\gamma$ production. The total 143 number of $\mathrm{CMV}$-specific IFN $\gamma \mathrm{CD}^{+}$and $\mathrm{IFN} \gamma \mathrm{CD}^{+} \mathrm{T}$ cells was calculated by 144 multiplying the percentages of $\mathrm{CMV}$-specific $\mathrm{T}$ cells producing IFN $\gamma$ upon stimulation 145 (after background subtraction) by the absolute $\mathrm{CD}^{+}$and $\mathrm{CD}^{+} \mathrm{T}$ cell counts. The 146 specific responses were considered those $>0.1 \%$ for both $\mathrm{CD} 4^{+}$and $\mathrm{CD} 8^{+} \mathrm{T}$ cells.

147 Immunological monitoring was performed once or twice a week during episodes of 148 active CMV infection. For some patients, several blood samples drawn after resolution 149 of the episode of active CMV infection were available for immunological analysis. A 
150 total of 146 blood samples from the 18 patients (median 7 samples; range, $2-15$ samples)

151 were analyzed.

\section{Sequence analysis of the UL54 and UL97 genes}

153 CMV DNA extraction from plasma specimens was carried out using the High Pure

154 nucleic acid kit (Roche Diagnostics, GmbH, Manheim, Germany). The extracted viral

155 DNA was used as a template for amplification of a 975 bp region of the UL97 gene

156 spanning codons 429 to 753 , and two regions of the UL54 gene spanning codons 345 to

157625 , and 645 to 1,013, as previously described [Tormo et al., 2009]. The PCR products

158 were purified by the QIAquick purification kit (Qiagen GmbH, Hilden, Germany),

159 sequenced by the ABI Prism BigDye Terminator Cycle Sequencing Kit v3.1 (PE

160 Applied Biosystems), and analyzed on an ABI 310 automated DNA sequencer.

161

\section{Statistical analysis}

162 Data were analyzed with the aid of the statistical package SPSS (version 15.0).

163 Comparisons were carried out using the non-parametric Mann-Whitney U-test for

164 unpaired continuous data and the Wilcoxon test for paired continuous data. The

165 Spearman rank test was used for analysis of correlation between continuous variables.

166 For calculation purposes undetectable CMV-specific responses were computed as 0

167 cells $/ \mu \mathrm{L}$. A $P$ value $<.05$ was considered statistically significant.

168

169

170

171

172

173

174 
175

176

177

178

179

180

181

182

183

184

185

186

187

188

189

190

191

192

193

194

195

196

197

198

\section{RESULTS}

\section{Features of episodes of active CMV infection}

Nineteen episodes of active CMV infection (in 18 patients) were included for analysis. The episodes occurred at a median of 56 days post-transplant (range, 14 to 330 days). Thirteen out of the 19 episodes (in 12 patients) resolved within the study period (Table II). The remaining 6 episodes (in 6 patients) were still active at the end of the follow up, after a median of 30 days (range 14 to 97 days) of initiation of pre-emptive therapy (Table III). Three out of these 6 patients died during the study period (the cause of death was bacterial sepsis in one patient and severe GvHD in the other 2 patients).

(84)

\section{CMV-specific $T$ cells at the time of initiation of pre-emptive therapy}

We firstly assessed the CMV-specific T-cell response at the time of initiation of preemptive therapy. Blood samples for immunological analysis were available from 14 episodes ( 9 of them developed before day 100 post-transplant). Undetectable IFN $\gamma$ $\mathrm{CD}^{+}$and $\mathrm{CD}^{+}{ }^{+}$-cell responses were observed in 13 out of the 14 episodes. In the remaining episode, which was still active at the end of the follow up, low levels of both CMV-specific T-cell subsets were detected $\left(0.03 \mathrm{IFN} \gamma \mathrm{CD}^{+} \mathrm{T}\right.$ cells $/ \mu \mathrm{L}$ and $0.26 \mathrm{IFN} \gamma$ $\mathrm{CD} 4^{+} \mathrm{T}$ cells $\left./ \mu \mathrm{L}\right)$. Nine out of the 14 episodes resolved within the study period, with the time to negative conversion of CMV DNAemia varying widely (3 to 94 days), while no control of CMV replication was achieved in the remaining 5 episodes. These data indicated that peripheral levels of IFN $\gamma \mathrm{CD}^{+}$and IFN $\gamma \mathrm{CD} 4^{+} \mathrm{T}$ cells at the time of initiation of pre-emptive therapy were not predictive of the virological outcome of the episode. 

Kinetics of CMV-specific T cells and CMV DNAemia during episodes of Active CMV infection

201 We investigated the dynamics of both CMV-specific T-cell subsets and CMV 202 DNAemia during 19 pre-emptively treated episodes of active CMV infection. Overall, 203 peripheral counts of IFN $\gamma \mathrm{CD}^{+}$and IFN $\gamma \mathrm{CD}^{+} \mathrm{T}$ cells inversely correlated with CMV 204 DNAemia levels ( $\sigma=-0.806 ; P=<0.001$, and $\sigma=-712 ; P=0.003$, respectively), yet 205 detectable CMV-specific T-cell responses were observed in the presence of CMV 206 DNAemia at some time points, both in unresolved episodes and in episodes which 207 eventually cleared. We found however, that IFN $\gamma \mathrm{CD}^{+}$(median, 0.38 cells $/ \mu \mathrm{L}$; range, $2080.03-1.28$ cells $/ \mu \mathrm{L}$ ) and $\mathrm{IFN} \gamma \mathrm{CD}^{+}$(median, 0.32 cells $/ \mu \mathrm{L} ;$ range, $0.06-1.27$ cells $/ \mu \mathrm{L}$ )

209 T-cell levels in the presence of CMV DNAemia were significantly lower $(P=<0.000$ for $210 \mathrm{IFN} \gamma \mathrm{CD}^{+}$and $P=<0.003$ for IFN $\gamma \mathrm{CD}^{+} \mathrm{T}$ cells) than IFN $\gamma \mathrm{CD} 8^{+}$(median, 2.46 211 cells $/ \mu \mathrm{L}$; range $0.82-15.02$ cells $/ \mu \mathrm{L}$ ) and IFN $\gamma \mathrm{CD}^{+}$(median 0.56 cells $\mu \mathrm{L}$; range, $2120.12-5.2$ cells $/ \mu \mathrm{L}$ ) T-cell levels at the time of the first negative PCR result. Taking into 213 consideration the peak value for $\operatorname{IFN} \gamma \mathrm{CD}^{+} \mathrm{T}$ cells $(1.28$ cells/ $\mu \mathrm{L})$ found in the 214 presence of CMV DNAemia, a threshold value of 1.3 cells/ $\mu \mathrm{L}$ predicting $\mathrm{CMV}$ 215 DNAemia clearance (negative PCR) was established in our cohort (PPV, 100\%; NPV, 216 93\%). A certain degree of overlap was found between IFN $\gamma \mathrm{CD}^{+} \mathrm{T}$ cell values in the 217 presence of CMV DNAemia and those at the time of the first negative PCR result. Thus, 218 setting a threshold $(1.3$ cells $/ \mu \mathrm{L})$ above the peak value $(1.27$ cells $/ \mu \mathrm{L})$ found in the 219 presence of CMV DNAemia resulted in a lower NPV (75\%). Therefore, the number of 220 IFN $\gamma \mathrm{CD}^{+} \mathrm{T}$ cells was a more reliable marker for predicting CMV DNAemia clearance 221 in our cohort.

222 Three different kinetic patterns of IFN $\gamma \mathrm{CD}^{+}$and IFN $\gamma \mathrm{CD} 4^{+} \mathrm{T}$ cells were observed 223 in relation to CMV DNAemia: (i) A rapid expansion within the first week after 
224 initiation of pre-emptive therapy (median 7 days; range 3 to 7 days) concomitant with 225 CMV DNAemia clearance was observed in 5 episodes (see episodes 1 to 5 in Table II). 226 An expansion within the third week (days 15 and 16) was observed in 2 additional 227 episodes (see episodes 6 and 7 in Table II). Overall, median increases of 2.09 IFN $\gamma$ $228 \mathrm{CD}^{+} \mathrm{T}$ cells $/ \mu \mathrm{L}$ (range, $0.9-15.13$ cells/ $\mu \mathrm{L}$ ) and of $0.67 \mathrm{IFN} \gamma \mathrm{CD} 4^{+} \mathrm{T}$ cells $/ \mu \mathrm{L}$ (range, $2290.12-5.20$ cells/ $\mu \mathrm{L}$ ) from baseline were observed in these episodes. None of these 230 patients was under corticosteroid treatment during the episode of active CMV infection. 231 Figure 1A depicts a representative episode of this kinetics pattern (episode 4 in Table II); 232 (ii) An early expansion (median 8 days; range 5 to 21 days) of a lower magnitude 233 (median increase of 0.57 IFN $\gamma \mathrm{CD}^{+} \mathrm{T}$ cells/ $\mu \mathrm{L}-$ range, $0.21-1.2$ cells/ $\mu \mathrm{L} P=0.02-$, and 234 of $0.29 \mathrm{IFN} \gamma \mathrm{CD} 4^{+} \mathrm{T}$ cells/ $\mu \mathrm{L}-$ range, $\left.0.01-0.62 ; P=0.063-\right)$ than that observed in rapidly 235 cleared episodes with delayed resolution of CMV DNAemia (median 31 days, range 20 236 to 94 days), concomitant with a further expansion of both T-cell subsets (median 237 increase of $3.05 \mathrm{IFN} \gamma \mathrm{CD}^{+} \mathrm{T}$ cells $/ \mu \mathrm{L}$ and of $0.42 \mathrm{IFN} \gamma \mathrm{CD} 4^{+} \mathrm{T}$ cells/ $\mu \mathrm{L} ; \mathrm{P}=0.001$ and $238 \mathrm{P}=0.04$, respectively) was observed in 6 episodes (see episodes 8 to 13 in Table II); 239 Figure 1B illustrates a representative example of this kinetics pattern (data for the 240 episode 8 in Table II). The two longest episodes (episodes 8 and 11) occurred in 241 patients under treatment with corticosteroids for grade III-IV GvHD, and their 242 resolution was coincident with steroid dose tapering; (iii) An inconsistent or a lack of 243 expansion of IFN $\gamma \mathrm{CD}^{+}$(median, 0.06 cell/ $\mu \mathrm{L}$ ) and IFN $\gamma \mathrm{CD} 4^{+} \mathrm{T}$ cells (median, 0,22 244 cell/ $\mu \mathrm{L} ; \mathrm{P}=0.001$ and $\mathrm{P}=0.03$, respectively, in relation to $\mathrm{T}$-cell increases measured in 245 cleared episodes) with persistent CMV DNAemia that was still detectable at the end of 246 the follow-up period was seen in 6 episodes (Table III). Three out of these 6 episodes 247 developed while patients were under corticosteroid therapy for severe GvHD. Figure 1C 248 shows the data for a representative case (episode 1 in Table III). The latest plasma 
249 samples available from the longest unresolved episodes (episodes 1 and 2 in Table III)

250 were screened for the presence of mutations known to confer resistance to ganciclovir

251 or foscarnet. No mutations were found in either sample.

252

CMV-specific $T$ cells after CMV DNAemia clearance and relapsing infections

255 None of the 12 patients in whom the episode of CMV DNAemia resolved during the

study period experienced a relapsing episode at least during the following month (only

one of these patients received maintenance valganciclovir therapy after CMV DNAemia clearance). Episodes 2 and 3 in Table II developed in the same patient; However, the relapsing episode occurred 6 months after the resolution of the preceding one. Blood samples obtained at the time of interruption of antiviral therapy (second antigenemia test or PCR giving a negative result) were available for 8 episodes. A median of 2.8 IFN $\gamma \mathrm{CD}^{+} \mathrm{T}$ cells $/ \mu \mathrm{L}$ (range 0.68 to 19.5 cells $/ \mu \mathrm{L}$ ) and of $0.38 \mathrm{IFN} \gamma \mathrm{CD} 4^{+} \mathrm{T}$ cells $/ \mu \mathrm{L}$ (range 0.19 to 2.28 cells/ $\mu \mathrm{L}$ ) was found. Follow-up samples obtained after cessation of

264 antiviral therapy (range 3 to 86 days) were available from 4 episodes. Detectable though

265 fluctuating levels of both IFN $\gamma \mathrm{CD}^{+}$and IFN $\gamma \mathrm{CD}^{+} \mathrm{T}$ cells were observed over time 266 (see the Figure 1, panel A for a representative example), with a median of 5.1 IFN $\gamma$

$267 \mathrm{CD}^{+} \mathrm{T}$ cells $/ \mu \mathrm{L}$ (range 0.57 to 47.7 cells $/ \mu \mathrm{L}$ ) and $0.41 \mathrm{IFN} \gamma \mathrm{CD} 4^{+} \mathrm{T}$ cells $/ \mu \mathrm{L}$ (range 2680.19 to 3.31 cells $/ \mu \mathrm{L})$.

\section{CMV-specific $\mathrm{T}$ cells in patients with $\mathrm{CMV}$ disease}

271 CMV enteritis was diagnosed in 3 patients in the setting of corticosteroid treatment 272 for GvHD (Table II, episode 13, and Table III, episodes 4 and 5). In all cases, 273 undetectable CMV-specific T-cell responses were observed at the onset of the clinical 
274 manifestations of the disease. Interestingly, in patient 12 (episode 13 in Table II), CMV

275 DNAemia clearance and a notable improvement in clinical symptoms were related to a 276 marked expansion of IFN $\gamma \mathrm{CD}^{+} \mathrm{T}$ cells, which occurred after steroid dose tapering.

277 The remaining 2 patients failed to expand CMV-specific T cells and had persistent 278 CMV DNAemia. Both patients died during the follow-up period.

281 Several conclusions can be drawn from our data. Firstly, peripheral counts of both

IFN $\gamma \mathrm{CD}^{+}$and IFN $\gamma \mathrm{CD}^{+}$T-cell subsets inversely correlated with CMV DNAemia levels during episodes of active CMV infection. Similar data were obtained in earlier studies using pp65 peptide-tetramers [Aubert et al., 2001] or ICS [Widmann et al., 2008] to assess the $\mathrm{CMV}$-specific $\mathrm{CD} 8^{+}$and $\mathrm{CD}^{+} \mathrm{T}$-cell responses, respectively. In the latter study however, levels of CMV peptide-specific $\mathrm{CD}^{+} \mathrm{T}$ cells did not correlate with viremia [Widmann et al., 2008]. In another study [Avetisyan et al., 2006], patients who had detectable $\mathrm{CMV}$-specific IFN $\gamma \mathrm{CD}^{+}{ }^{+}$-cell responses at week 4 after allo-SCT 289 displayed lower peak mean viral loads compared with patients who lacked a detectable 290 response. Furthermore, the degree of decline in CMV-specific T cells early after transplant has been associated with the development of CMV viremia [Eid et al., 2009].

292 In our study, the median levels of both CMV-specific functional T-cell subsets were 293 significantly lower in the presence of CMV DNAemia than at the time of the first 294 negative PCR result. A threshold value of 1.3 cells $/ \mu \mathrm{L}$ for both T-cell populations 295 predicting CMV DNAemia clearance was established in our cohort, the number of IFN $\gamma$ $296 \mathrm{CD}^{+} \mathrm{T}$ cells being a more reliable marker. These cut-off cell levels are remarkably 297 close to those previously determined by us [Solano et al., 2008] and by other groups 298 [Hebart et al., 2002; Ohnishi et al., 2005; Lilleri et al., 2008; Moins-Teisserenc et al., 
299 2008, Pourgheysari et al., 2009] (different functional T-cell types) providing protection

300 against development of CMV antigenemia or DNAemia.

301 Secondly, in agreement with a previous report by our group [Solano et al., 2008], we

302 found that ultimate control of CMV replication in the course of antiviral therapy

303 depended on a robust and sustained expansion of $\operatorname{IFN} \gamma \mathrm{CD}^{+} \mathrm{T}$ cells, and - to a lesser

304 extent - of IFN $\gamma \mathrm{CD}^{+}{ }^{+} \mathrm{T}$ cells. A notable expansion of both T-cell subsets concomitant

305 with CMV DNAemia clearance was seen as soon as one week after initiation of pre-

306 emptive therapy in 5 episodes, although, overall, T-cell expansion controlling CMV

307 replication was observed at a median of 15 days after implementation of therapy. In line

308 with our findings, the peak median level of expanding pp65-specific functional $\mathrm{CD}^{+} \mathrm{T}$

309 cells was reported to occur around 20 days after CMV reactivation [Hakki et al., 2003].

310 In contrast, failure to expand both functional T-cell populations in response to CMV

311 replication resulted in persistent CMV DNAemia despite antiviral treatment and the fact

312 that the emergence of resistant strains was not documented (in the two longest episodes).

313 Three out of the 6 episodes that remained active at the end of the follow up occurred

314 in the setting of corticosteroid therapy for GvHD, supporting the well known fact that

315 corticosteroids impair the reconstitution of the CMV-specific T-cell response in a dose-

316 dependent manner [Hakki et al., 2003; Gratama et al., 2008].

317 Thirdly, the marked expansion of functional CMV-specific $\mathrm{T}$ cells and the

318 maintenance of peripheral pools of these T-cell subsets after CMV DNAemia clearance

319 and cessation of antiviral therapy prevented the occurrence of relapsing episodes of

320 active CMV infection at least during the following month. A similar conclusion was

321 reached in earlier studies [Lilleri et al., 2008; Gratama et al., 2008; Moins-Teisserenc et

322 al., 2008]. 
323 Three patients developed CMV enteritis. In accordance with a previous report

324 [Avetisyan et al., 2006], in all cases clinical onset of disease occurred in the face of 325 undetectable IFN $\gamma \mathrm{CD} 8^{+}$and $\mathrm{CD}^{+}$T-cell responses. One of these patients recovered 326 from CMV disease, and clinical improvement, as well as CMV DNAemia clearance, 327 was concomitant with a robust expansion of both functional CMV-specific T-cell 328 populations.

329 Our data may have several implications for the therapeutic management of active 330 CMV infection in the allo-SCT recipient. A strategy of deferred antiviral therapy based 331 on the detection of a CMV-specific immune response by ELISPOT at the time of CMV 332 DNAemia detection was safely applied in a number of patients late (around 3 months) 333 after transplant [Avetisyan et al., 2007]. In our cohort, however, no patient stratification 334 could be established according to the magnitude of the CMV-specific T-cell response at 335 the time of initiation of pre-emptive therapy, as all but one patient displayed 336 undetectable responses. The lack of a detectable CMV-specific T-cell response, 337 however, was not predictive of the outcome of CMV infection in terms of the duration 338 of CMV DNAemia. Thus, no patients from our cohort would have benefited from the 339 abovementioned strategy. Our study and that of Avetisyan et al. [2007], however, differ 340 in the method employed for enumeration of CMV-specific functional T cells, and most

341 importantly, in the time frame in which active CMV infections occurred (early after 342 transplant in most of our patients and late after transplant in theirs). Further studies are 343 required to determine the clinical usefulness of this therapeutic approach.

344 Early interruption (or dose reduction) of pre-emptive therapy provided that a 345 significant expansion of $\mathrm{CMV}$-specific $\mathrm{T}$ cells is documented may be a potential 346 intervention strategy based on immunological monitoring. Our data indicate that 347 peripheral levels of $\mathrm{CMV}$-specific IFN $\gamma \mathrm{CD} 8+\mathrm{T}$ cells above 1.3 cells/ $\mu \mathrm{L}$, which were 
348 shown to be associated with CMV DNAemia clearance, might be a reasonable threshold

349 at which to interrupt antiviral therapy. Our data do not allow us to be certain about the

350 virological efficacy and clinical safety of this approach, as the antiviral therapy course

351 was not suspended in our patients until a second negative antigenemia or PCR result.

352 This question can only be answered by means of a controlled clinical trial.

353 Relapsing episodes of active CMV infection develop at an exceedingly high rate

354 following the implementation of short duration pre-emptive treatment regimens

355 [Gimeno et al., 2008]. We have previously shown that their occurrence is related to the

356 presence of low peripheral levels of CMV-specific functional $\mathrm{T}$ cells after resolution of

357 the preceding episode [Tormo et al., 2009]. Data obtained in the present study extend

358 our previous observation. In effect, peripheral levels of both T-cell subsets above the

359 abovementioned cut-off at the time of virological clearance and interruption of antiviral

360 therapy consistently prevented the occurrence of relapsing episodes. In these patients a

361 sustained but rather fluctuating CMV-specific T-cell response was observed. On the

362 basis of this finding, maintenance antiviral therapy should be administered after CMV

363 DNAemia clearance provided that protective levels of functional CMV-specific T cell

364 are not reached at the end of the antiviral therapy course.

365 Adoptive transfer of CMV-specific functional $\mathrm{T}$ cells is a therapeutic option in 366 episodes of active CMV infections that do not respond to antiviral therapy [Einsele et al., 367 2008]. According to our data, a lack of consistent expansion of CMV-specific T cells is 368 associated with persistent CMV DNAemia, even in the absence of proven resistance to 369 antivirals. In this sense, it would be reasonable to consider this therapeutic strategy, 370 rather than switching antiviral therapy, in patients failing to respond to antivirals after 4 371 weeks of treatment (time at which expansion of functional CMV-specific $\mathrm{T}$ cells 372 eventually controlling CMV replication was documented in most of cleared episodes in 
373 our cohort), provided that corticosteroid therapy is not underway, and that emergence of

374 antiviral-resistant strains is ruled out.

375 In summary, our data suggest that routine immunological monitoring during episodes

376 of CMV DNAemia may yield useful information for the therapeutic management of

377 active CMV infection in allo-SCT recipients. Larger studies are nevertheless needed in

378 order to verify this assumption.

379

380

\section{ACKNOWLEDGMENTS}

381 We thank all the staff of the Microbiology Service of the Hospital Clínico

382 Universitario for technical assistance. This research was supported by a grant (06/1738)

383 from FIS (Fondo de Investigaciones Sanitarias, Ministerio de Sanidad y Consumo, 384 Spain).

385

386

387

388

389

390

391

392

393

394

395

396

397

John Wiley \& Sons 
399 Aubert G, Hassan-Walker AF, Madrigal AJ, Emery VC, Morte C, Grace S, Koh MB,

400 Potter M, Prentice HG, Dodi IA, Travers PJ. 2001. Cytomegalovirus-specific 401 cellular immune responses and viremia in recipients of allogeneic stem cell 402 transplants. J Infect Dis 184: 955-963.

403 Avetisyan G, Aschan J, Hägglund H, Ringdén O, Ljungman P. 2007. Evaluation of 404 intervention strategy based on CMV-specific immune responses after allogeneic 405 SCT. Bone Marrow Transplant 40: 865-869.

406 Avetisyan G, Aschan J, Hägglund H, Ringdén O, Ljungman P. 2007. Evaluation of 407 intervention strategy based on CMV-specific immune responses after allogeneic 408 SCT. Bone Marrow Transplant 40: 865-869.

409 Boeckh M, Nichols WG, Papanicolau G, Rubin R, Wingard JR, Zaia J. 2003.

410 Cytomegalovirus in hematopoietic stem cell transplant recipients: Current status, 411 known challenges, and future strategies. Biol Blood Marrow Transplant 9: 543412558.

413 Eid AJ, Brown RA, Hogan WJ, Lahr BD, Eckel-Passow JE, Litzow MR, Razonable RR. 414 2009. Kinetics of interferon-gamma producing cytomegalovirus (CMV)-specific 415 CD4+ and CD8+ lymphocytes and the risk of subsequent CMV viremia after 416 allogeneic hematopoietic stem cell transplantation. Transplant Infect Dis 11:519$417 \quad 528$.

418 Einsele H, Kapp M, Grigoleit GU. 2008. CMV-specific T-cell therapy. Blood Cells Mol 419 Dis $40: 71-75$.

420 Foster AE, Gottlieb DJ, Sartor M, Hertzberg MS, Bradstock KF. 2002. 421 Cytomegalovirus-specific CD4+ and CD8+ T-cells follow a similar 
422

423

424

425

426

427

428

429

430

431

432

433

434

435

436

437

438

439

440

441

442

443

444

445

reconstitution pattern after allogeneic stem cell transplantation. Biol Blood Marrow Transplant 8: 501-511.

Gimeno C, Solano C, Latorre JC, Hernández-Boluda JC, Clari MA, Remigia MJ, Furió

S, Calabuig M, Tormo N, Navarro D. 2008. Quantification of DNA in plasma by an automated real-time PCR assay (CMV PCR Kit, Abbott) for surveillance of active cytomegalovirus infection and guidance of pre-emptive therapy for allogeneic hematopoietic stem cell transplant recipients. J Clin Microbiol 46: $3311-3318$.

Griffiths P, Whitley R, Snydman DR, Singh N, Boeckh M. 2008. Contemporary management of cytomegalovirus infection in transplant recipients: Guidelines from an IHMF workshop, 2007. Herpes 15: 1-12.

Gratama JW, Brooimans RA, van der Holt B, Sintnicolaas K, van Doornum G, Niesters HG, Löwenberg B, Cornelissen JJ. 2008. Monitoring cytomegalovirus IE-1 and pp65-specific CD4+ and CD8+ T-cell responses after allogeneic stem cell transplantation may identify patients at risk for recurrent CMV reactivations. Cytometry Part B 74B: 211-220.

Hakki M, Riddell SR, Storek J, Carter RA, Stevens-Ayers T, Sudour P, White K, Corey L, Boeckh M. 2003. Immune reconstitution to cytomegalovirus after allogeneic stem cell transplantation: Impact of host factors, drug therapy, and subclinical reactivation. Blood 102: 3060-3067.

Hebart H, Daginik S, Stevanovic S, Grigoleit U, Dobler A, Baur M, Rauser G, Sinzger C, Jahn G, Loeffler J, Kanz L, Rammensee HG, Einsele H. 2002. Sensitive detection of human cytomegalovirus peptide-specific cytotoxic T-lymphocyte responses by interferon- $\gamma$ enzyme-linked immunospot assay and flow cytometry 

in healthy individuals and in patients after allogeneic stem cell transplantation. Blood 99: 3830-3837.

Lilleri D, Fornara C, Chiesa A, Caldera D, Alessandrino EP, Gerna G. 2008. Human cytomegalovirus-specific CD4+ and CD8+ T-cell reconstitution in adult allogeneic hematopoietic stem cell transplant recipients and immune control of viral infection. Haematologica 93: 248-256

Ljungman P. 2006. Would monitoring CMV immune responses allow improved control of CMV in stem cell transplant patients? J Clin Virol 35: 493-495.

Moins-Teisserenc H, Busson M, Scieux C, Bajzik V, Cayuela JM, Clave E, de Latour

Ljungman P. CMV infections after hematopoietic stem cell transplantation. 2008. Bone Marrow Transplant 42: S70-S72. RP, Agbalika F, Ribaud P, Robin M, Rocha V, Gluckman E, Charron D, Socié G, Toubert A. 2008. Patterns of cytomegalovirus reactivation are associated with distinct evolutive profiles of immune reconstitution after allogeneic hematopoietic stem cell transplantation. J Infect Dis 198: 818-826.

Ohnishi M, Sakurai T, Heike Y, Yamazaki R, Kanda Y, Takaue Y, Mizoguchi H, Kawakami Y. 2005. Evaluation of cytomegalovirus-specific T-cell reconstitution in patients after various allogeneic haematopoietic stem cell transplantation

467 Pourgheysari B, Piper KP, McLarnon A, Arrazi J, Bruton R, Cook M, Mahendra P, 468 Craddock C, Moss PAH. 2009. Early reconstitution of effector memory CD4+ 
469

470

471

472

473

474

475

476

477

478

479

480

481

482

483

484

485

486

487

488

489

490

491

492

CMV-specific $\mathrm{T}$ cells protects against CMV reactivation following allogeneic SCT. Bone Marrow Transplant 43 :853-861.

Quinnan GV, Kirmani N, Rook AH, Manischewitz JF, Jackson L, Moreschi G, Santos GW, Saral R, Burns WH.1982. Cytotoxic T cells in cytomegalovirus infection: HLA-restricted T-lymphocyte and non T-lymphocyte cytotoxic responses correlate with recovery from cytomegalovirus infection in bone-marrowtransplant recipients. N Engl J Med 307: 7-13.

Reusser P, Riddell SR, Meyers JD, Greenberg PD. 1991.Cytotoxic T-lymphocyte response to cytomegalovirus after human allogeneic bone marrow transplantation: pattern of recovery and correlation with cytomegalovirus infection and disease. Blood 78: 1373-1380.

Riddell SR, Watanabe KS, Goodrich JM, Li CR, Agha ME, Greenberg PD. 1992. Restoration of viral immunity in immunodeficient humans by the adoptive transfer of T cell clones. Science 257: 238-241.

Solano C, Benet I, Clari MA, Nieto J, de la Cámara R, López J, Hernández-Boluda JC, Remigia MJ, Jarque I, Calabuig ML, Garcia-Noblejas A, Alberola J, Tamarit A, Gimeno C, Navarro D. 2008. Enumeration of CMV-specific IFN $\gamma \mathrm{CD} 8^{+}$and $\mathrm{CD}^{+} \mathrm{T}$ cells early after allogeneic stem cell transplantation may identify patients at risk of active CMV infection. Haematologica 93: 1434-1436.

Solano C, Muñoz I, Gutiérrez A, Farga A, Prósper F, García-Conde J, Navarro D, Gimeno C. 2001. Qualitative plasma assay (AMPLICOR CMV test) versus pp65 antigenemia assay for monitoring cytomegalovirus viremia and guiding preemptive ganciclovir therapy in allogeneic stem cell transplantation. J Clin Microbiol 39: 3938-3941. 

493 Tormo N, Solano C, Benet I, Clari MA, Nieto J, de la Cámara R, López J, López-
494 Aldeguer N, Hernández-Boluda JC, Remigia MJ, Garcia-Noblejas A, Gimeno C,
495 Navarro D. 2009. Lack of prompt expansion of cytomegalovirus pp65 and IE-1-
496 specific IFNgamma CD8(+) and CD4(+) T cells is associated with rising levels
497 of pp65 antigenemia and DNAemia during pre-emptive therapy in allogeneic
498 hematopoietic stem cell transplant recipients. Bone Marrow Transplant Jul 20
$499 \quad$ [Epub ahead of print].

500 Widmann T, Sester U, Gärtner BC, Schubert J, Pfreundschuh M, Köhler H, Sester

501 M.2008. Levels of CMV specific CD4 T cells are dynamic and correlate with

502 CMV viremia after allogeneic stem cell transplantation. PLoS ONE 3: 1-12.

503

504

505

506

507

508

509

510

511

512

513

514

515

516

John Wirey \& Sons 
517 FIGURE 1. Representative patterns of kinetics of CMV pp65 and IE-1-specific IFN $\gamma$ 518 producing $\mathrm{CD}^{+}$(IFN $\gamma \mathrm{CD}^{+}$-open circles-) and $\mathrm{CD}^{+}$(IFN $\left.\gamma \mathrm{CD} 4^{+}\right) \mathrm{T}$ cells (black 519 diamonds) and CMV DNAemia (triangles) during episodes of active CMV infection. (A) 520 Patient displaying an early expansion of CMV-specific T cells (specially involving the $521 \mathrm{IFN} \gamma \mathrm{CD}^{+}$T-cell subset) concomitant with CMV DNAemia resolution. Fluctuating 522 levels of both T-cell populations were observed after interruption of antiviral therapy in 523 the absence of CMV DNAemia; (B) Patient displaying an early expansion of both 524 functional T-cell populations with delayed clearance of CMV DNAemia concomitant 525 with a further expansion of CMV-specific T cells; Fluctuating levels of both T-cell 526 subsets were observed prior to ultimate expansion leading to CMV DNAemia resolution 527 (C) Patient failing to expand either CMV-specific functional T-cell subset and 528 displaying persistent CMV DNAemia. This patient was under antiviral therapy 529 throughout the observational period. The arrow (AT) points out to the time at which 530 antiviral therapy was interrupted. 
TABLE I. Demographic and clinical data of the patients.

\begin{tabular}{|c|c|}
\hline Parameter & \\
\hline Patients & 18 \\
\hline Median age, yrs (range) & $52.5(17-67)$ \\
\hline Sex, no. male patients/no. female patients & $12 / 6$ \\
\hline \multicolumn{2}{|l|}{ Diagnosis, $n^{\circ}$ patients (\%) } \\
\hline Non-Hodgkin`s lymphoma & $8(44)$ \\
\hline Acute myeloid leukaemia & $4(22)$ \\
\hline Multiple myeloma & $3(16)$ \\
\hline Myelodysplastic syndrome & $2(11)$ \\
\hline Chronic lymphocytic leukaemia & $1(6)$ \\
\hline \multicolumn{2}{|l|}{ CMV serostatus, $\mathbf{n}^{0}$ patients (\%) } \\
\hline $\mathrm{D}+/ \mathrm{R}+$ & $9(50)$ \\
\hline $\mathrm{D}-/ \mathrm{R}+$ & $6(33)$ \\
\hline $\mathrm{D}+/ \mathrm{R}-$ & $3(16)$ \\
\hline \multicolumn{2}{|l|}{ Donor type, $n^{0}$ patients (\%) } \\
\hline HLA-identical sibling & $10(55)$ \\
\hline Matched unrelated donor & $5(28)$ \\
\hline Mismatched related donor & $3(16)$ \\
\hline \multicolumn{2}{|l|}{ Conditioning regimen, $\mathrm{n}^{\mathbf{0}}$ patients $(\%)$} \\
\hline Non-myeloablative & $14(77)$ \\
\hline Myeloablative & $4(22)$ \\
\hline \multicolumn{2}{|l|}{ Stem cell source } \\
\hline Peripheral blood & $16(88)$ \\
\hline Umbilical cord blood & $1(6)$ \\
\hline Bone marrow & $1(6)$ \\
\hline \multicolumn{2}{|l|}{$\begin{array}{l}\text { Acute or chronic GvHD during episodes } \\
\text { of active CMV infection }\end{array}$} \\
\hline Grades 0-I & $12(66)$ \\
\hline Grades II-IV & $6(33)$ \\
\hline
\end{tabular}


TABLE II. Virological and immunological data of episodes of active CMV infection, the resolution of which occurred during the study period.

\begin{tabular}{|c|c|c|c|c|c|}
\hline \multirow[t]{2}{*}{$\begin{array}{l}\text { Episode } \\
\text { (Day PT) }\end{array}$} & \multicolumn{3}{|c|}{$\begin{array}{l}\text { CMV DNAemia } \\
\text { (Copies/mL) }\end{array}$} & \multicolumn{2}{|c|}{$\begin{array}{l}\text { CMV-specific T-cell response } \\
\left.\text { IFN } \gamma \mathrm{CD} 8^{+} / \mathrm{IFN} \gamma \mathrm{CD} 4^{+} \text {(cells } / \mu \mathrm{L}\right)\end{array}$} \\
\hline & Initial & Peak & $\begin{array}{l}\text { Duration } \\
\text { (days) }\end{array}$ & $\begin{array}{l}\text { First detected } \\
\text { response (day) }\end{array}$ & $\begin{array}{l}\text { At first negative PCR } \\
\text { (day) }\end{array}$ \\
\hline $1(232)$ & 1125 & 1125 & 7 & $15.13 / 0.12(7)$ & $-{ }^{*}$ \\
\hline $2(115)$ & 800 & 800 & 3 & $2.09 / 1.61(3)$ & - \\
\hline $3(293)$ & 2460 & 2460 & 7 & $15.20 / 5.20(7)$ & - \\
\hline $4(41)$ & 890 & 890 & 7 & $14.01 / 1.90(7)$ & - \\
\hline $5(40)$ & 1800 & 1800 & 6 & $1.31 / 0.43(6)$ & - \\
\hline $6(59)$ & 560 & 1200 & 15 & $0.90 / 0.38(15)$ & - \\
\hline $7(14)$ & 1100 & 3200 & 16 & $1.45 / 0.67$ (16) & - \\
\hline $8(30)$ & 1100 & 6200 & 94 & $0.50 / 0.40(21)$ & $6.24 / 0.55(94)$ \\
\hline $9(26)$ & 1980 & 1980 & 20 & $0.65 / 0.19(7)$ & $0.82 / 0.56(20)$ \\
\hline $10(53)$ & 3600 & 4560 & 55 & $0.21 / 0.62(21)$ & $2.46 / 1.23(55)$ \\
\hline $11(63)$ & 1270 & 3700 & 61 & $0.22 / 0.01(7)$ & $1.36 / 0.48(61)$ \\
\hline $12(27)$ & 1200 & 3100 & 31 & $0.67 / 0.06(5)$ & $4.34 / 0.70(31)$ \\
\hline $13(65)$ & 7200 & 15110 & 31 & $1.28 / 0.46(9)$ & $10.62 / 0.35(31)$ \\
\hline
\end{tabular}


TABLE III. Virological and immunological data of episodes of active CMV infection that were still active at the end of the study period.

\begin{tabular}{|c|c|c|c|c|c|}
\hline \multirow[t]{2}{*}{$\begin{array}{l}\text { Episode } \\
\text { (Day PT) }\end{array}$} & \multicolumn{2}{|c|}{$\begin{array}{l}\text { CMV DNAemia } \\
\text { (Copies } / \mathrm{mL})\end{array}$} & \multicolumn{2}{|c|}{$\begin{array}{l}\text { CMV-specific T-cell response } \\
\left.\text { IFN } \gamma \mathrm{CD} 8^{+} / \text {IFN } \gamma \mathrm{CD}^{+}{ }^{+} \text {(cells } / \mu \mathrm{L}\right)\end{array}$} & \multirow[t]{2}{*}{ Treatment } \\
\hline & Initial & $\begin{array}{l}\text { Peak } \\
\text { (day) }\end{array}$ & $\begin{array}{l}\text { First detectable } \\
\text { response (day) }\end{array}$ & $\begin{array}{l}\text { Peak level } \\
\text { (day) }\end{array}$ & \\
\hline $1(330)$ & 2390 & $3790(7)$ & $0.96 / 0.19(20)$ & $-^{*}$ & FOS/VGCV \\
\hline $2(62)$ & 2320 & $35,450(12)$ & $1.28 / 1.27(8)$ & - & VGCV \\
\hline $3(160)$ & 1350 & $10,200(30)$ & $0.03 / 0.06(7)$ & - & VGCV \\
\hline $4(42)$ & 5440 & $5500(9)$ & $0.09 / 0.46(9)$ & - & FOS \\
\hline $5(55)$ & 5600 & $23,450(19)$ & ND & ND & VGCV \\
\hline $6(36)$ & 720 & $1290(23)$ & $0.03 / 0.26(0)$ & $0.53 / 0.66(8)$ & GAN \\
\hline
\end{tabular}

FOS, Foscarnet; VGCV,Valganciclovir; GAN, Ganciclovir; ND, Not detectable; PT, Post-transplant. Day in columns refers to days after initiation of pre-emptive therapy. *-, The peak level was the first detected response. 

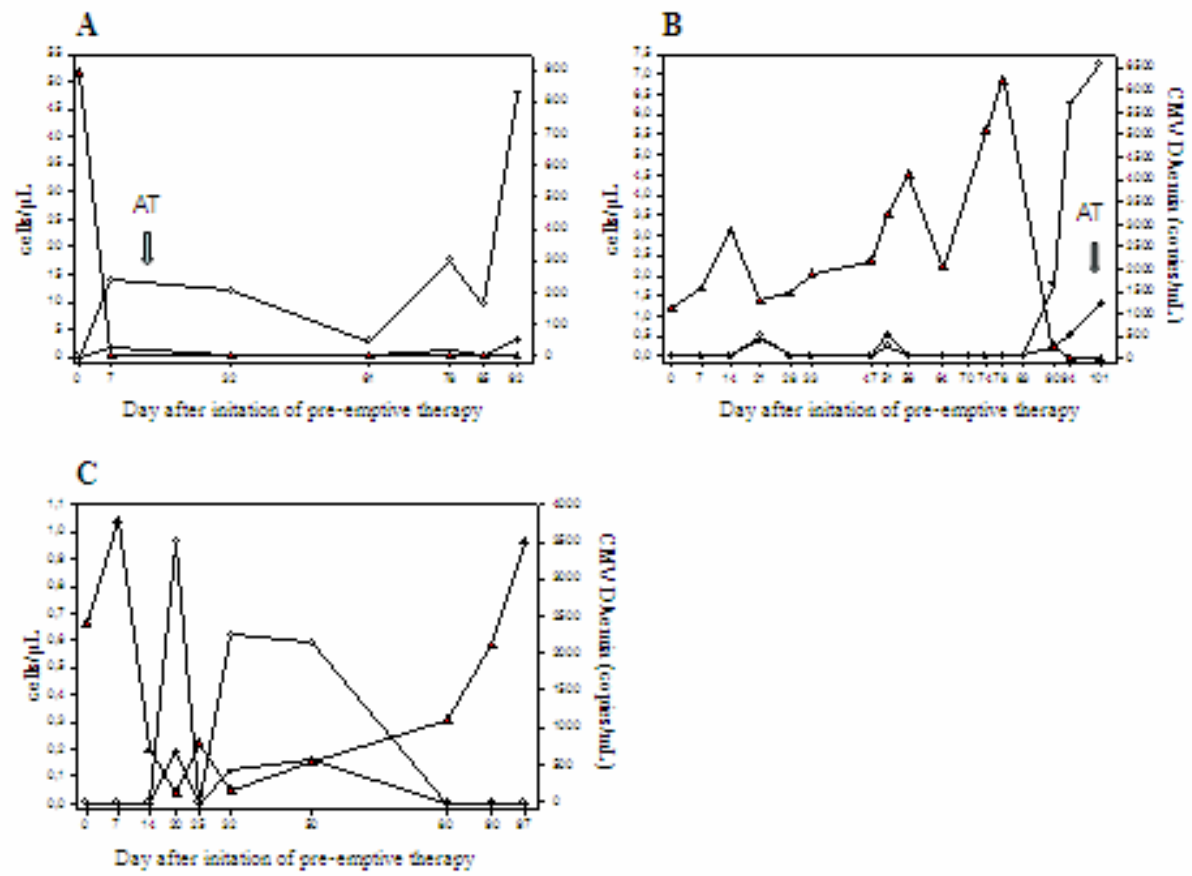